\title{
Efectele tehnologiilor de exploatare a Iemnului asupra unor parametri fizici ai solurilor forestiere montane
}

\section{Barbu}

\section{Introducere}

Dintre activităţile de exploatare a pădurilor, colectarea lemnului este cea care crează cele mai acute conflicte, de natură să pună în discuţie problema mecanizării în raport conflictual cu conservarea capacităţii de producţie a pădurii (Barbu, 1979; Ciobanu, 1979; Constantinescu,
Barbu I. 2020. Research concerning the effects of wood harvesting techniques on the physical parameters of forest soils. Bucov. For. 20(1): 23-31

Abstract. The paper deal with the impacts of different wood logging techniques on the soil parameters in the spruce forests of Eastern CarpathiansRomania. Experiments were made in soils formed on two geological substrates (crystalline schist's and flish) and shows the changes induced in the bulk density, moisture \%, and time of infiltration of $100 \mathrm{~mm}$ water column, in two kinds of wood harvesting: heavy tractors and logging with horses. Measurements made with standardizes methods shows increasing of bulk density of the soils until $30-40 \mathrm{~cm}$ deep. On the loamy - sandy soils the bulk density increase from $0.6 \mathrm{~g} / \mathrm{cm}^{3}$ to $1.15 \mathrm{~g} / \mathrm{cm}^{3}$ in the first $15 \mathrm{~cm}$. On the soils developed on flisch, the bulk density increase in the first $5 \mathrm{~cm}$ from $0.6 \mathrm{~g} / \mathrm{cm}^{3}$ to $0.84 \mathrm{~g} / \mathrm{cm}^{3}$. The infiltration time of a $100 \mathrm{~mm}$ water column increase of 10-15 times, mainly on the soils developed on flish at $1-10 \mathrm{~cm}$. At $20 \mathrm{~cm}$ in the soil deep the infiltration time increase of 3-3.6 times under the tractors extraction roads and 1-1.2 times under the horses extraction roads. The consequences of soil compaction on the functioning of soils and forest are discussed and some measures for the reduction of the impacts are proposed.

Keywords: soil compaction, bulk density, soil moisture, infiltration, wood harvesting, Bukovina.

Author. Barbu Ion (ionbarbu51@gmail.com) - "Marin Drăcea" National ResearchDevelopment Institute in Forestry, Station Câmpulung Moldovenesc, 73bis, Calea Bucovinei, 725100 Câmpulung Moldovenesc, Romania

Manuscript received December 26, 2019; revised May 02, 2020; accepted May 27, 2020; online first July 20. 
ploatarea) să insiste mai mult pentru crearea şi folosirea unor utilaje şi instalaţii mecanice perfecţionate corespunzătoare unor tehnologii noi şi cu impact redus pentru ecosistemul forestier (Barbu, Cenuşă, 1984; Copăceanu, ş.a., 1983).

Echilibrul dintre cerinţele tehnicii de cultură silvică intensivă şi cerinţele tehnologiilor de exploatare - cu alte cuvinte armonizarea celor două categorii de interese - se poate realiza în mod satisfăcător doar în condiţiile unor adaptări tehnologice care să permită creşterea productivităţii muncii la exploatarea lemnului concomitent $\mathrm{cu}$ reducerea pagubelor produse solului, seminţişului şi arborilor rămaşi în pădure (Ciobanu, 1979; Vlad, 1957; Vlad, Petrescu, 1977).

Nivelul de eficienţă ecologică a exploatărilor forestiere şi eficacitatea tehnico-economică sunt condiţionate de realizarea următoarelor obiective:

i) sporirea accesibilităţii încă nesatisfăcătoare pentru unele păduri, prin construirea de drumuri auto principale şi secundare (Bereziuc, 1987; Barbu, Cenuşă, 1987, 2001);

ii) reducerea distanţelor de colectare a lemnului (în interiorul arboretului) prin crearea şi folosirea căilor secundare, inclusiv a drumurilor de coastă (Ciobanu, 1979; Barbu, Cenuşă, 2001);

iii) înzestrarea unităţilor de exploatare cu mijloace tehnice corespunzătoare (trolii, funiculare) pentru colectarea lemnului (Copăceanu, 1983);

iv) limitarea folosirii tractoarelor forestiere în perioadele ploioase (Ciobanu, 1979; Barbu, Cenuşă, 2001);

v) extinderea tehnologiilor de exploatare cu ajutorul instalaţiilor cu cablu, care nu prezintă dezavantajele tractoarelor sub raportul impactului asupra solurilor şi seminţişului (Copceanu, 1983; Oprea, 1995).

Cercetările efectuate în cadrul Laboratorului de Ecologie din Institutul Naţional de Cercetare Dezvoltare în Silvicultură „Marin Drăcea”, asupra tehnologiilor de exploatare folosite în prezent în arboretele de molid, au condus la concluzia că, printr-o analiză detaliată a fiecă- rei operaţiuni şi faze pe principii ergonomice şi silviculturale, se pot aduce perfecţionări care să permită, pe de o parte, diminuarea vătămărilor produse solului, puieţilor şi arborilor rămaşi, iar pe de altă parte, să contribuie la mai buna organizare a procesului tehnologic în ansamblu şi la creşterea productivităţii muncii, concomitent cu reducerea consumurilor de carburant (Barbu şi Cenuşă, 2001).

Cercetări similare din lume au relevat efectul activităţilor de exploatare realizate cu tractoare de tip articulat asupra greutăți volumetrice a solului, în sensul creșterii valorilor acesteia, și, respectiv, scăderea valorilor porozităţii totale ale solului (Proto et al., 2015; Solgi și Najafi, 2014, Jang et al. 2015, Lacey et al., 1994).

Rezultatele pe care le prezentăm în continuare fac parte dintr-un program mai complex de investigare a impactului tehnologiilor de exploatare a lemnului asupra ecosistemului forestier şi au ca obiectiv final soluţii tehnice şi tehnologice de diminuare a acestui impact.

\section{Material și metodă}

Pentru studierea impactului tehnologiilor de exploatare a lemnului în păduri montane de molid s-au realizat cercetări complexe care au vizat următoarele aspecte:

i) evaluarea pagubelor produse la doborârea şi colectarea lemnului asupra arborilor rămaşi şi seminţişurilor instalate; precum şi a

ii) pagubelor produse la colectarea lemnului asupra litierei şi solurilor.

Principalii parametri de cuantificare a impactului asupra solurilor au urmărit evidenţierea modului de degradare a solurilor forestiere, precum şi frecvenţa şi intensitatea de manifestare a acestora. Rezultatele au servit la cartarea degradării solurilor în scopul optimizării proceselor tehnologice.

Pentru stabilirea suprafeţei afectate de diferite forme de degradare s-a conceput un sistem de eşantionaj geometric, aplicat după o rețea raster $(25 \times 25 \mathrm{~m})$, pe toată suprafaţa arboretelor studiate. Datele au fost recoltate din su- 
Tahel1 Principalele caracteristici ale suprafeţelor experimentale în care s-a determinat influenţa utilajelor folosite la colectarea lemnului asupra parametrilor fizici ai solurilor de pe traseele de colectare Main characteristics of experimental plots installed in wood collection pathways where were determined the influence of forest machines used in wood harvesting on soil physical characteristics

\begin{tabular}{|c|c|c|c|c|c|c|c|c|c|c|c|c|c|}
\hline \multirow{2}{*}{$\begin{array}{l}\text { Ocolul } \\
\text { silvic }\end{array}$} & \multirow{2}{*}{ U.P. } & \multirow{2}{*}{ u.a. } & \multirow{2}{*}{$\begin{array}{l}\text { Substrat } \\
\text { geologic }\end{array}$} & \multirow{2}{*}{$\begin{array}{c}\text { Panta } \\
\left({ }^{\circ}\right)\end{array}$} & \multirow{2}{*}{$\begin{array}{l}\text { Depozit de } \\
\text { suprafaţă }\end{array}$} & \multirow{2}{*}{$\begin{array}{l}\mathrm{Nr} . \\
\text { tre- } \\
\text { ceri }\end{array}$} & \multirow{2}{*}{$\begin{array}{c}\text { Grosimea } \\
\text { fiziologică } \\
\text { a solului } \\
(\mathrm{cm})\end{array}$} & \multicolumn{3}{|c|}{$\begin{array}{c}\text { Nr. profile } \\
\text { analizate }\end{array}$} & \multirow{2}{*}{$\begin{array}{l}\text { Nr. } \\
\text { repe- } \\
\text { tiţii }\end{array}$} & \multirow{2}{*}{$\begin{array}{l}\text { Nr. } \\
\text { ori- } \\
\text { zon- } \\
\text { turi }\end{array}$} & \multirow{2}{*}{$\begin{array}{l}\text { Nr. } \\
\text { probe } \\
\text { ana- } \\
\text { liz. }\end{array}$} \\
\hline & & & & & & & & Martor & TAF & $\overline{\text { Atelaje }}$ & & & \\
\hline Tomnatic & I & $37 \mathrm{~B}$ & Fliş & 10 & $\begin{array}{c}\text { Depozit } \\
\text { de versant } \\
\text { argilo-lutos }\end{array}$ & 10 & $>60$ & 1 & 1 & 1 & 3 & 4 & 36 \\
\hline \multirow[t]{3}{*}{ Pojorâta } & III & $167 \mathrm{E}$ & \multirow{3}{*}{$\begin{array}{c}\text { Şisturi } \\
\text { cristaline }\end{array}$} & 15 & Depozit & 10 & $>60$ & 3 & 2 & 2 & 3 & 4 & 84 \\
\hline & III & 168 & & 10 & de versant & 10 & $>60$ & 2 & 1 & - & 3 & 4 & 36 \\
\hline & II & 129 & & 18 & luto-nisipos & 10 & $>60$ & 1 & 1 & 1 & 3 & 4 & 36 \\
\hline
\end{tabular}

\section{FORMATIUNI GEOLOGICE IN OCOÁLELE SILVICE DIN JUDETTUL SUCEAVA}

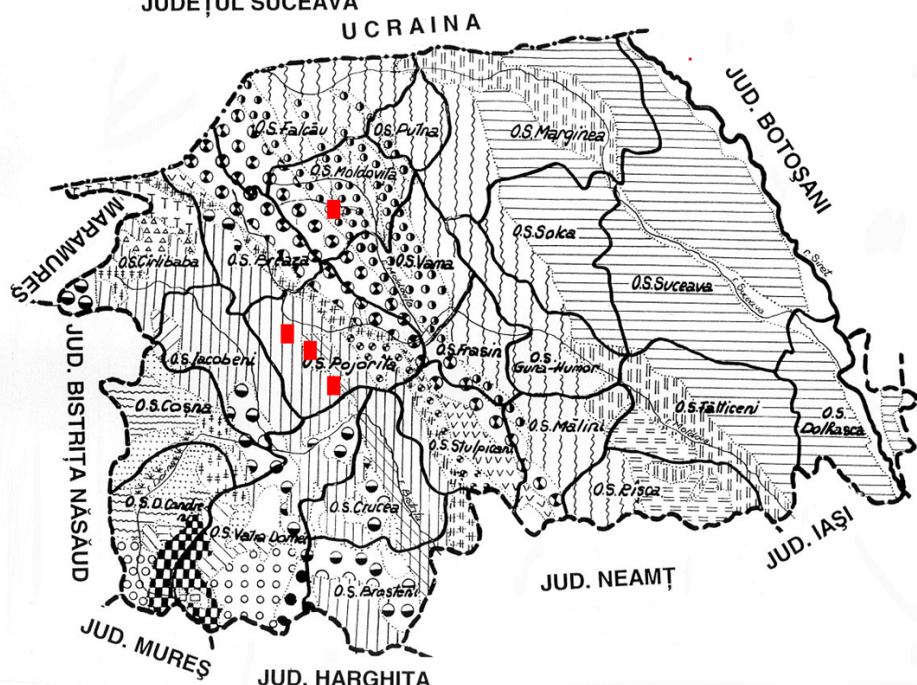

LEGENDA :

Marne cenuşii și gresii Marne argiloase cu intercalatii de nisipuri Terase (nisipuri şi pietrişuri) Fliş grezos (gresia de Tarcău și Prisaca) - Fliş grezos cu intercalații şistoase conglomerate cu elemente de şisturi vez

Flis şistos negru (Strate de Audia) Flis şistos-grezos cu intercalații de gresii massive si conglomerate (flis curbicortical)

HA Fliş grezos-calcaros-sistos (strate de Sinaia)

- Fliş grezos-şistor (strate de Bistra)

. Sisturi cristaline (gnais de Rarău) Conglomerate şi gresii grosier Calcare și dolomite cristaline Sisturi cristaline (filite, şisturi sericito-cloritoase) Sisturi epimetamorfice
Facies grezos conglomeratic

Formatiuni vulcanogen-sedimendate

- Andezite cu piroxeni

Diorite şi microdiorito

2 Roci piroclastice

Porfiroide

Dacite

Facies marnos

Depozite de mlaştină (turbării)

Gresii calcaroase (tip Borşa)

Depozite cuaternare

Figura 1 Localizarea cercetărilor pentru studierea influenţei tehnologiilor de exploatare asupra compactării solurilor forestiere în județul Suceava

Study location of experimental plots where were analyzed the influence of harvesting technologies on forest soil compaction at Suceava Forest Directorate level

prafeţe de probă de $10 \mathrm{~m}^{2}(5 \times 2 \mathrm{~m})$, orientate pe curba de nivel şi au fost sintetizate în fişe de teren special concepute.

Pentru determinarea impactului asupra caracteristicilor fizice ale solurilor la trecerea tractoarelor şi atelajelor s-au ales patru arborete reprezentative din Ocolul silvic Tomnatic (U.P. I Demacuşa, u.a. 37B) din cadrul INCDS
„Marin Drăcea” şi Ocolul silvic Pojorâta (U.P. III Valea Putnei, u.a. 167 E, 168; U.P. II Giumalău, u.a. 129) din cadrul Direcţiei Silvice Suceava (tabelul 1, figura 1).

Pentru probele recoltate, s-a determinat densitatea aparentă considerând masa unităţii de volum de sol uscat (în $\mathrm{g} / \mathrm{cm}^{3}$ ) a solului la adâncimi standard: $0 \mathrm{~cm}(0-5 \mathrm{~cm}), 10 \mathrm{~cm}$ 


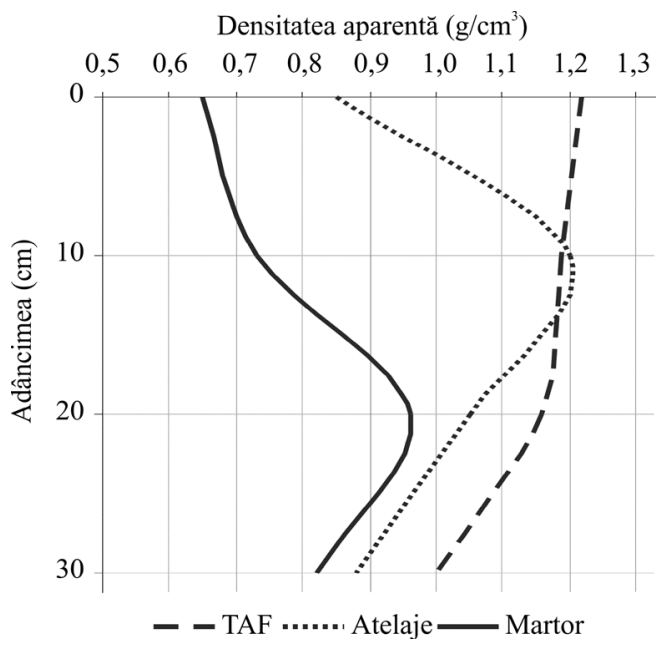

Figura 2 Influenţa tractoarelor şi atelajelor folosite la colectarea lemnului asupra densităţii aparente a solului format pe şisturi cristaline. Depozit de versant luto-nisipos. Ocolul silvic Pojorâta, U.P. III Valea Putnei, u.a. 167 E.

The influence of forest tractors and machines used in wood collection on soil bulk density formed on crystalline schists. Deposit on the clay-sandy slope. Pojorâta Forest District, UP III, Valea Putnei, u.a. 167 E.

$(10-15 \mathrm{~cm}), 20 \mathrm{~cm}(20-25 \mathrm{~cm})$ şi $30 \mathrm{~cm}(30-$ $35 \mathrm{~cm})$. Determinarea umidităţii solului s-a făcut în laborator, pentru probe recoltate cu cilindrul, după metoda standardizată (ICPA). Viteza de infiltrare a apei s-a determinat in-situ, pe profilul de sol săpat în trepte din 10 in $10 \mathrm{~cm}$. Infiltrometrul folosit a fost conceput în laboratorul INCDS ,Marin Drăcea” şi constă dintr-un cilindru cu diametrul de $100 \mathrm{~mm}$. Măsurătorile constau în înregistrarea timpului de infiltrare a unei coloane de apă de $100 \mathrm{~mm}$ în orizonturile standard, în condiţiile experimentale date.

\section{Rezultate}

\section{Influenţa utilajelor asupra densităţii aparente a solurilor}

Măsurarea densităţii aparente a solului la diferite adâncimi, după 10 treceri ale tractorului 26

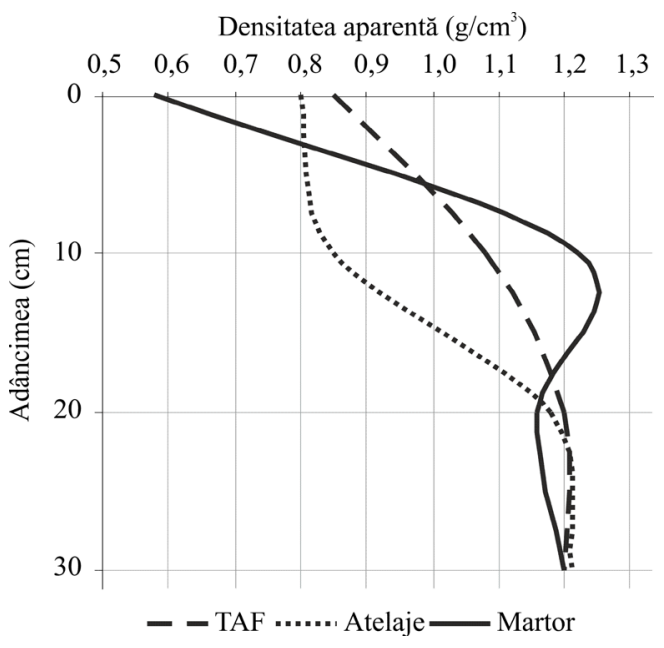

Figura 3 Influenţa tractoarelor şi atelajelor folosite la colectarea lemnului asupra densităţii aparente a solului format pe substrat de fliş. Depozit de versant argilo-lutos. Ocolul silvic Tomnatic, U.P. I Demacuşa, u.a. 37 B.

The influence of forest tractors and machines used in wood collection on soil bulk density formed on flysch. Deposit on the clay slope. Tomnatic Forest District, UP I, Demăcuşa, u.a. $37 B$.

forestier sau ale atelajelor, a scos în evidență o modificare a acesteia comparativ cu solul situat în suprafața martor, indiferent că substratul este de fliş sau şisturi cristaline. Se constată astfel că în zonele nederanjate de trecerea tractorului sau vitelor, densitatea în primii 10 $\mathrm{cm}$ are valori $0,65-0,75 \mathrm{~g} / \mathrm{cm} 3$ în solurile formate pe şisturi cristaline şi $0,58-1,23 \mathrm{~g} / \mathrm{cm} 3$ în solurile formate pe substrate de fliş tipice în Obcina Feredeului. La aceeaşi adâncime, după 10 treceri ale TAF-ului, densitatea creşte la $1,18-1,23 \mathrm{~g} / \mathrm{cm} 3$ pe soluri formate pe şisturi cristaline şi la $0,8-0,9 \mathrm{~g} / \mathrm{cm} 3$ pe soluri formate pe fliş. Pe traseele de colectare cu atelajele compactarea este mai redusă şi a condus la densităţi de $0,85-1,2 \mathrm{~g} / \mathrm{cm} 3$ pe cristalin şi 0,85-1,08 g/cm3 pe fliş. La adâncimi mai mari de $20 \mathrm{~cm}$, diferenţele se menţin pe profilul solului de pe substrat cristalin şi se estompează pe profilul solului format pe fliş. Pe solurile formate pe depozitul luto-nisipos din Munţii 
Giumalău, diferenţa de densitatea se menţine chiar şi la adâncimi de $30 \mathrm{~cm}$ fiind de $0,82 \mathrm{~g} /$ cm3 în profilul martor, $0,89 \mathrm{~g} / \mathrm{cm} 3 \mathrm{sub}$ traseul de tractor şi $1,0 \mathrm{~g} / \mathrm{cm} 3$ pe traseul de tras colectare cu vitele (figurile 2 și 3 ).

\section{Influenţa utilajelor asupra umidităţii solului}

Cercetările s-au făcut în timpul sezonului de vegetaţie (luna iulie) într-o perioadă cu precipitaţii apropiate de media lunară $(80-100 \mathrm{~mm})$, la 8-10 zile după ultima ploaie mai mare de $5 \mathrm{~mm}$.

Din analiza rezultatelor măsurătorilor s-a constatat că efectele tehnicilor de colectare experimentate sunt diferite în funcţie de substrat, dar şi în funcţie de structura solului şi a caracteristicilor orizontului humifer. Astfel, în zona nederanjată (martor), umiditatea la adâncimea de $0-5 \mathrm{~cm}$ este de $46 \%$, de $23 \%$ în porţiunea afectată de colectarea cu animalele, iar pe traseul de colectare cu tractorul, de $68 \%$.

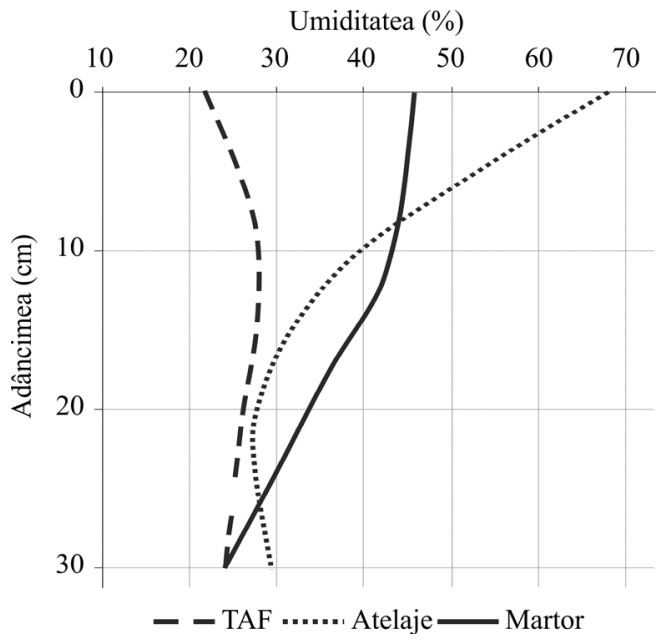

Figura 4 Influența tractoarelor şi atelajelor folosite la colectarea lemnului asupra umidităţii solului format pe şisturi cristaline. Depozit de versant luto-nisipos. Ocolul silvic Pojorâta, U.P. III Valea Putnei, u.a. 167 E.

The influence of forest tractors and machines used in wood collection on the soil moisture formed on crystalline schists. Deposit on the clay-sandy slope. Pojorâta Forest District, UP III, Valea Putnei, u.a. 167 E.
Probabil că stagnarea apei în urma trecerii repetate a tractorului explică valoarea înregistrată în cazul respectiv, la fel cum cea înregistrată la trecerea vitelor s-ar putea explica prin reducerea porozităţii solului. La adâncimi de 10-20 $\mathrm{cm}$, influenţa sistemelor de colectare asupra umidităţii solurilor se menţine, dar la cu diferenţe mai mici. Astfel, la 10-15 cm adâncime, umiditatea solului în suprafaţa martor este de $43 \%$, pe traseul de tractor $40 \%$, iar pe cel de colectare cu animalele, de $28 \%$ (figurile 4 și 5).

La adâncimea de $20-25 \mathrm{~cm}$, în suprafaţa martor umiditatea a fost de $34 \%$, iar pe traseele de colectare cu tractorul, de $28 \%$. Pe traseul de colectare cu vitele, umiditatea medie a fost de $22 \%$. La adâncimi de peste $30 \mathrm{~cm}$, practic diferenţele se estompează.

Se poate concluziona că pe solurile formate pe substrate de şisturi cristaline, diferențele în ceea ce priveşte capacitatea de reţinere a apei sunt foarte mari în primii $20-30 \mathrm{~cm}$ şi scad pro-

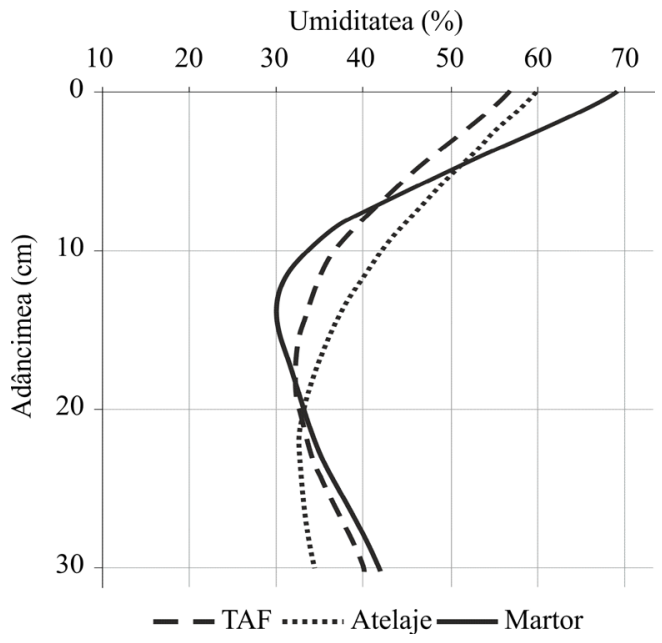

Figura 5 Influența tractoarelor şi atelajelor folosite la colectarea lemnului asupra dasupra umidităţii solului format pe substrat de fliş. Depozit de versant argilo-lutos. Ocolul silvic Tomnatic, U.P. I Demacuşa, u.a. 37 B.

The influence of forest tractors and machines used in wood collection on the soil moisture formed on flysch. Deposit on the clay slope. Tomnatic Forest District, UP I, Demăcușa, u.a. $37 B$. 
gresiv de la suprafaţă spre adâncime.

Pe solurile formate pe substrate de fliş (figura 5), diferenţele induse de trecerea TAFurilor şi a atelajelor la colectarea lemnului sunt mai puţin marcante asupra umidităţii solurilor. Valorile umidităţii solului sunt mai mari la suprafaţă pe teren nederanjat şi mai mici pe traseele de colectare. După adâncimea de $20 \mathrm{~cm}$, practic diferenţele se estompează.

O concluzie generală se desprinde din analiza prezentată: pe traseele de colectare a lemnului capacitatea de reţinere a apei pe profil este mult mai mică decât în restul suprafeței. Adesea, datorită compactării solului în orizonturile superioare, dispar porii mari care reţin apa gravitaţională, iar apa din precipitaţii stagnează la suprafaţa solurilor, favorizând apariţia unor fenomene de pseudogleizare şi colonizarea acestor trasee cu specii higrofile (Deschampsia sp., Molinia coerulea, Juncus sp.).

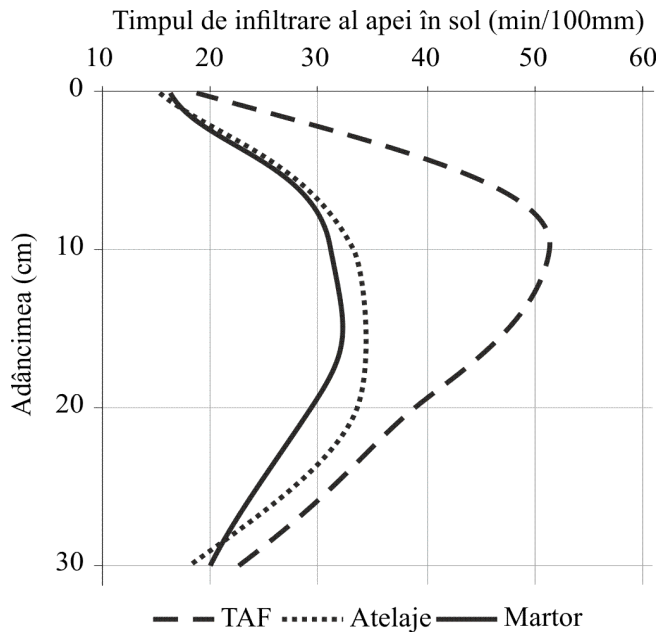

Figura 6 Influenţa tractoarelor şi atelajelor folosite la colectarea lemnului asupra vitezei de infiltrare a apei în solul format pe şisturi cristaline. Depozit de versant luto-nisipos. Ocolul silvic Pojorâta, U.P. III Valea Putnei, u.a. 167 E.

The influence of forest tractors and machines used in wood collection on the infiltration speed of water in soil formed on crystalline schists. Deposit on the clay-sandy slope. Pojorâta Forest District, UP III, Valea Putnei, u.a. 167 E.

\section{Influenţa tehnologiilor de colectare a lemnului asupra vitezei de infiltrare a apei în sol}

Rolul pădurii şi al solurilor forestiere în modificarea bilanţului hidrologic este binecunoscut prin efectele favorabile asupra retenţiei apei în coronament şi în litieră, dar mai ales prin infiltrarea unei importante cantităţi de apă din precipitaţii în sol, de unde aprovizionează arborii şi pânza freatică. $\mathrm{Cu}$ cât viteza de infiltrare a apei în sol este mai mare, cu atât scurgerea la suprafaţa solului este mai redusă şi, ca urmare, se reduce şi se întârzie debitul de viitură la apariţia unor episoade de precipitaţii abundente. Invers, cu cât timpul de infiltrare al unei coloane de apă este mai lung, cu atât mai mult creşte scurgerea la suprafaţa solului şi riscul de inundaţii.

Cercetările noastre au vizat determinarea experimentală a timpului de infiltrare a unei

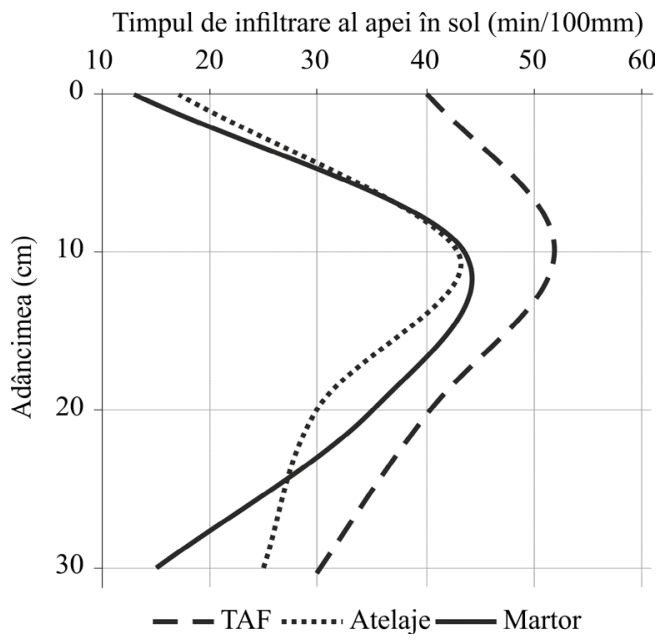

Figura 1 Influenţa tractoarelor şi atelajelor folosite la colectarea lemnului asupra vitezei de infiltrare a apei în solul format pe substrat de fliş. Depozit de versant argilo-lutos. Ocolul silvic Tomnatic, U.P. I Demacuşa, u.a. 37 B.

The influence of forest tractors and machines used in wood collection on the infiltration speed of water in soil formed on flysch. Deposit on the clay slope. Tomnatic Forest District, UP I, Demăcușa, u.a. 37B. 
coloane de apă de 100 mm în porţiuni de pădure afectate şi neafectate (martor) de trecerea repetată a utilajelor folosite la colectarea lemnului. În figurile 6 şi 7 au fost reprezentate grafic rezultatele experimentale ale determinărilor timpului de infiltrare a unei coloane de apă de 100 mm la diferite adâncimi în sol pe teren nederanjat de trecerea utilajelor şi pe traseele de colectare. Pe substrate de şisturi cristaline, la adâncimea de $0-5 \mathrm{~cm}$, timpul de infiltrare a apei pe traseul de colectare cu tractorul este $\mathrm{cu}$ $20 \%$ mai lung, iar pe traseul de colectare cu vitele a fost comparabil cu cel din suprafaţa martor. La aceeaşi adâncime $(0-5 \mathrm{~cm})$, pe substrat de fliş, timpul de infiltrare a unei coloane de apă de pe traseul de colectare cu tractorul a fost de 10 ori mai mare decât în suprafaţa martor. Pe traseul de colectare a lemnului cu atelajele a fost în medie de 2 ori mai lung decât în suprafaţa martor.

La adâncimea de $10-15 \mathrm{~cm}$, pe substrat de şisturi cristaline, timpul de infiltrare al coloanei de apă este de 4 ori mai lung pe traseul de colectare cu tractorul şi nu diferă semnificativ de martor pe traseul de colectare cu vitele. Pe substrat de fliş, la aceeaşi adâncime pe profilul solului, timpul de infiltrare a apei pe traseul de colectare cu tractorul a fost de 1,3 ori mai lung decât timpul de infiltrare în suprafaţa martor şi sau pe traseul de colectare cu vitele.

Diferenţele între vitezele de infiltrare se menţin şi la adâncimi de $20-25 \mathrm{~cm}$, fiind, în medie, cu 30\% mai lungi pe traseele de colectare cu tractorul decât în suprafaţa martor.

$\mathrm{Ca}$ o remarcă generală, se poate aprecia că timpul de infiltrare a apei creşte mult mai intens în orizonturile superioare ale solurilor formate pe fliş decât în solurile formate pe substrate cristaline. Concluzia este de mare importanţă şi explică, în mare măsură în primul caz, creşterile de debite şi procesele de eroziune în adâncime a traseelor de colectare a lemnului din porţiunile de versant înclinate. În acelaşi mod se explică suprafeţele orizontale mult mai mari afectate de procesele de stagnare a apei şi modificarea regimului aero-hidric în solurile formate pe substrate de fliş din Obcinile Bucovinei.

\section{Discuții şi concluzii}

În toate suprafeţele experimentale cercetate s-a constatat vătămarea solului în orizonturile superioare ca urmare a colectării lemnului. Silvicultural, prin tratamentele aplicate, se urmăreşte regenerarea naturală a molidului şi a speciilor de amestec, însă vătămarea solului are efecte negative asupra regimului apei şi aerului din sol şi, implicit, asupra regenerării naturale. Principalele modificări morfologice ale solului determinate de trecerea repetată a utilajelor folosite la colectarea lemnului sunt:

i) distrugerea orizontului de litieră şi a unei părţi din orizontul humifer în interiorul arboretelor (5-10\% din suprafaţă), în special pe traseele de colectare a lemnului;

ii) tasarea şi compactarea solului până la adâncimea de $25-30 \mathrm{~cm}$, în cazul unor treceri repetate cu utilajele;

iii) formarea unui orizont subţire cu caractere de pseudogleizare (pete ruginii pe particule de sol) în partea superioară $(12-15 \mathrm{~cm})$ a solurilor cu textură luto-argiloasă formate pe depozite de fliş;

iv) apariţia unor suprafețe cu exces de umiditate pe traseele căilor de colectare a lemnului, înierbate puternic cu Juncus sp., Deschampsia caespitosa şi Molinia coerulea (3-5\% din suprafaţă pe substrate cristaline şi $5-15 \%$ pe substrate de fliş);

v) declanşarea unor procese de eroziune în suprafaţă şi în adâncime în special pe versanţi.

Cercetările efectuate şi-au propus cuantificarea modificărilor morfo-funcţionale ale solurilor pe traseele folosite pentru colectarea lemnului în pădure. Rezultatele obţinute permit formularea unor concluzii cu caracter general: i) trecerea tractoarelor cu sarcină peste solul forestier determină creşterea densităţii aparente a solului în primii 30-40 cm. Pe solurile luto-nisipoase creşterea este de la $0,6 \mathrm{~g} / \mathrm{cm}^{3}$ la $1,0 \mathrm{~g} /$ $\mathrm{cm}^{3}$ în primii $5 \mathrm{~cm}$ de la suprafaţă şi de la 0,95 $\mathrm{g} / \mathrm{cm}^{3}$ la $1,15 \mathrm{~g} / \mathrm{cm}^{3}$ la adâncimea de $30 \mathrm{~cm}$;

ii) pe solurile argilo-lutoase formate pe fliş, la o singură trecere a TAF-ului, densitatea solului în primii $5 \mathrm{~cm}$ a crescut de la $0,6 \mathrm{~g} / \mathrm{cm}^{3} \mathrm{la} 0,84 \mathrm{~g} / \mathrm{cm}^{3}$; 
iii) colectarea lemnului cu vitele determină creşterea densităţii aparente a solului doar în primii 10-20 cm; tasările cele mai puternice se înregistrează la suprafaţa solului $(0-10 \mathrm{~cm})$; iv) pe traseele de colectare cu tractorul, creşterea densităţii aparente se transmite în sol până la adâncimea de $30 \mathrm{~cm}$ pe soluri formate pe substrat de şisturi cristaline şi până la $20 \mathrm{~cm}$ pe fliş;

v) pe căile de colectare cu TAF şi vite timpul de infiltrare a unei coloane de apă de $100 \mathrm{~mm}$ rămâne aproape constant în primii $10 \mathrm{~cm}$ la solurile formate pe şisturi cristaline şi creşte de $10-15$ ori pe solurile argiloase formate pe depozite de fliş;

vi) la adâncimea de $20 \mathrm{~cm}$ timpul de infiltrare a unei coloane de apă de $100 \mathrm{~mm}$ creşte în medie de 3-3,6 ori pe traseele de colectare cu TAF şi de 1-1,2 ori pe traseele de colectare cu vitele, comparativ cu solul nederanjat.

Efectul trecerii repetate a utilajelor folosite în exploatarea masei lemnose asupra proprietăților solului, a fost analizat și în munții din sudul Italiei, în arborete cu Fagus silvatica şi Abies alba, ajungându-se la rezultate similare celor din România, în sensul că, la un număr de 15 treceri consecutive, densitatea solului a crescut cu $53 \%$ în primii $10 \mathrm{~cm}$ ai profilului (de la $0,75 \mathrm{~g} / \mathrm{cm}^{3}$ la suprafețele martor la 1,15 $\mathrm{g} / \mathrm{cm}^{3}$ la cele circulate repetat) (Proto et al., 2015).

Rezultate asemănătoare au fost înregistrate și în arborete cu Fagus orientalis din nordul Iranului, unde trecerea repetată a tractoarelor pe acelaşi traseu (de 13 ori) a condus la creșterea valorilor densității solului în primii $10 \mathrm{~cm}$ cu $57 \%$ și scăderea valorilor porozității totale cu 35\% (Solgi \& Najafi, 2014). Creșteri de peste $50 \%$ a valorilor densității aparente s-au înregistrat și în experimente similare în arborete din SUA (Lacey, et al., 1994)

Consecinţele ecologice ale tasărilor determinate de trecerea tractoarelor şi vitelor la colectarea lemnului din pădure sunt următoarele: modificarea structurii solului; reducerea porozităţii de aeraţie în primii $20-30 \mathrm{~cm}$; stagnarea apelor din precipitaţii; pseudogleizarea 30 solului şi înierbarea cu specii hidrofile (Juncus sp., Deschampsia caespitosa, Molinia coerulea); înrăutăţirea condiţiilor pentru instalarea şi dezvoltarea regenerării naturale. Pe această bază, este necesară stabilirea şi marcarea vizibilă a căilor de colectare cu vitele şi cu tractorul şi interzicerea accesului utilajelor grele (TAF) în interiorul arboretelor, în afara traseelor stabilite.

Luând în considerare şi experimentările efectuate în colaborare cu Institutul Naţional al Lemnului (Copăceanu et al., 1983), se recomandă anumite sisteme de colectare a masei lemnoase în condiţiile aplicării tratamentelor cu tăieri de regenerare la margine de masiv în molidişuri şi amestecuri de răşinoase cu fag (Barbu, Cenuşă, 2001).

Astfel, pentru tăierile unice (rase) se recomandă liniile tehnologice:

i) colectarea completă cu funicularul sau tractorul, în benzi late de $40 \mathrm{~m}$ sau $60 \mathrm{~m}$ şi lungime variabilă (în funcţie de lungimea versantului); ii) colectare mixtă; adunatul şi scosul cu atelaje şi apropiatul cu funicularul sau tractorul, în benzi late de până la $80 \mathrm{~m}$ şi de lungime variabilă (în funcţie de lungimea versantului).

Pentru tăieri combinate şi succesive se recomandă următoarele linii tehnologice de colectare:

i) colectare completă cu funicularul sau tractorul, în benzi late de $40 \mathrm{~m}$ şi de lungime variabilă (în funcţie de lungimea versantului);

ii) colectare mixtă; adunatul şi scosul cu atejale şi apropiatul cu funicularul sau tractorul, în benzi late de 60 sau $80 \mathrm{~m}$ şi de lungime variabilă (în funcţie de lungimea versantului).

Alegerea liniilor principale de colectare se va face cu respectarea indicaţiilor prevăzute în „Normele de aplicare a tratamentelor”, după o analiză detaliată în teren.

O altă soluţie de perspectivă, care trebuie realizată încă din cadrul lucrărilor de amenajare, este tipizarea tehnologică a arboretelor în legătură cu tehnologia de exploatare, ca acţiune de planificare a aplicării tratamentelor de regenerare. Bazată pe criterii mixte (tehnico-culturale şi funcţionale), divizarea tehnologică a spaţiului pădurii are şi menirea deosebită de 
a crea posibilităţi pentru adaptarea pădurii la condiţiile mecanizării lucrărilor de exploatare. Aceasta se poate realiza prin gruparea suprafeţelor păduroase în unităţi de gospodărire permanente (în legătură cu exploatarea), respectiv în complexe tehnologice, fiecare unitate fiind omogenă în ceea ce priveşte condiţiile naturale (caracteristici ale arboretelor, tipul de sol, declivitatea etc.) şi de producţie (reţele de drumuri, locuri pentru depozite etc.). Fiecare entitate sau complex tehnologic, constituit dintr-un parchet (cupon) sau din mai multe parchete de exploatare, în care s-a autorizat acelaşi tip de mijloace de colectare, în cadrul aceloraşi soluţii tehnologice, ar prezenta un caracter de independență tehnică în raport cu aplicabilitatea practică (în funcţie de formă, mărime, accesibilitate etc.), dar şi un caracter de permanenţă derivat din aspecte fizice care asigură aplicarea în timp a măsurilor de gospodărire preconizate.

Necesitatea unei tipizări tehnologice se accentuează odată cu creşterea exigenţelor privind modalităţile de gospodărire intensivă a pădurilor (tratamente cu tăieri la margine de masiv pe suprafeţe mici, grădinărite etc.), care impun o atenţie deosebită în ceea ce priveşte colectarea, atât sub raporul cerinţelor producţiei (volum de muncă, productivitate, eficienţă economică etc.), cât şi sub cel al efectuării lucrărilor respective cu prejudicii minime aduse seminţişurilor, arborilor rămaşi în picioare şi solului. Din acest punct de vedere, tipizarea tehnologică capătă importanţă şi mai mare pentru arboretele din aflate în perioada de regenerare din planul decenal de recoltare pentru produse principale şi poate conduce la creşterea ponderii suprafeţelor regenerate natural şi la reducerea daunelor produse solului.

\section{Bihliografie}

Barbu I., 1979. Unele aspecte ecologice privind lucrările de exploatare a rupturilor și doborâturilor de zăpadă în pădurile din Bucovina. Revista Pădurilor 94(3):150-155

Bereziuc R., Oprița V., Olteanu N., 1987. Rețele de drumuri forestiere. Editura Ceres, Bucureşti, 246 p.

Barbu I., Cenuşă R., 1987. Asigurarea protecţiei arborete- lor de molid împotriva doborâturilor şi rupturilor produse de vânt si zăpadă . ICAS Seria II, Bucureşti, 1987, $71 \mathrm{p}$.

Barbu I., Cenuşă R., 2001. Regenerarea naturală a molidului. Ed. Tehnică Silvică, Bucureşti, 238 p.

Cenuşă R., Barbu I., 1984 - Asigurarea protecţiei arboretelor de molid prin aplicarea blocurilor şi succesiunilor de tăieri şi a tăierilor de îngrijire. ICAS referat ştiinţific final. Manuscris ICAS București.

Ciobanu P.ş.a., 1979. Tehnologii şi tratamente intensive de regenerare naturală în molidişuri, amestecuri de răşinoase cu fag şi făgete în condiţiile mecanizării lucrărilor de exploatare a lemnului. ICAS București.

Constantinescu, N., 1973. Regenerarea arboretelor. Editura Ceres, Bucureşti, $670 \mathrm{p}$.

Copacean D., Balanescu, Ghica, Rusu G., 1983. Tehnologia exploatării lemnului. Editura Ceres, Bucureşti, 347 p.

Jang W., Keyes Ch., Page-Dumroese D., 2015. Impact of Biomass Harvesting on Forest Soil Productivity in the Northern Rocky Mountains. Gen. Tech. Rep. RMRSGTR- 341. Fort Collins, CO: U.S. Department of Agriculture, Forest Service, Rocky Mountain Research Station. 35 p. https://doi.org/10.2737/RMRS-GTR-341

Lacey S.T., Ryan P.J., Huang J., Weiss, D.J, 1994. Soi lphysical proper1y change from forest harvesting in New South Wales. Research division state forests of New South Wales sydney research paper no. 25, August, 1994, $80 \mathrm{p}$.

Oprea I., 1995 - Organizarea şantierelor de exploatare a lemnului. Editura Didactică și Pedagogică București, $124 \mathrm{p}$.

Proto, A. R., Macrì, G., Sorgonà, A., Zimbalatti, G., 2016. Impact of Skidding Operations on Soil Physical Properties in Southern Italy. Contemporary Engineering Sciences, 23(9), 1095 - 1104. https://doi.org/10.12988/ ces.2016.68132

Solgi A. Najafi A., 2014. The impacts of ground-based logging equipment on forest soil. Journal of Forest Science, 60, 2014 (1): 28-34. https://doi.org/10.17221/76/2013-JFS.

Vlad I., 1957. Regenerarea naturală a molidului. Editura Agrosilvică, Bucureşti, 144p.

Vlad I., Petrescu L., 1977. Cultura molidului în România. Editura Ceres, Bucureşti, 359 p.

ICPIL, 1985 - Tehnici şi metode de lucru în exploatările forestiere în scopul creşterii productivităţii muncii. Bucureşti 